\title{
A new approach for modeling Cenozoic oceanic lithium isotope paleo-variations: the key role of climate
}

\author{
N. Vigier $^{1}$ and Y. Goddéris ${ }^{2}$ \\ ${ }^{1}$ Laboratoire d'Océanographie de Villefranche, CNRS, UPMC, 06230 Villefranche-sur-Mer, France \\ ${ }^{2}$ Géosciences Environnement Toulouse, CNRS, Université Paul Sabatier, 31400 Toulouse, France \\ Correspondence to: N. Vigier (nathalie.vigier@obs-vlfr.fr)
}

Received: 9 June 2014 - Published in Clim. Past Discuss.: 28 July 2014

Revised: 14 March 2015 - Accepted: 16 March 2015 - Published: 1 April 2015

\begin{abstract}
The marine record of ocean lithium isotope composition may provide important information constraining the factors that control continental weathering and how they have varied in the past. However, the equations establishing links between the continental flux of $\mathrm{Li}$ to the ocean, the continental $\mathrm{Li}$ isotope composition and the ocean $\mathrm{Li}$ isotope composition are under-constrained, and their resolution are related to significant uncertainties. In order to partially reduce this uncertainty, we propose a new approach that couples the $\mathrm{C}$ and $\mathrm{Li}$ cycles, such that our proposed reconstruction of the Cenozoic Li cycle is compatible with the required stability of the exospheric carbon cycle on geological timescales. The results of this exercise show, contrary to expectations, that the Cenozoic evolution of the $\mathrm{Li}$ isotope composition of rivers did not necessarily mimic the oceanic $\delta^{7} \mathrm{Li}$ rise. In contrast, variations in the continental flux of $\mathrm{Li}$ to the ocean are demonstrated to play a major role in setting the ocean $\delta^{7} \mathrm{Li}$. We also provide evidence that Li storage in secondary phases is an important element of the global Li cycle that cannot be neglected, in particular during the early Cenozoic. Our modeling of the published foraminifera record highlights a close link between soil formation rate and indexes recording the climate evolution during the Cenozoic, such as foraminifera $\delta^{18} \mathrm{O}$ and $p \mathrm{CO}_{2}$ reconstructions. This leads us to conclude that the $\mathrm{Li}$ isotope record does not provide persuasive, unique evidence for erosional forcing of Cenozoic change because it could alternatively be consistent with a climatic control on soil production rates.
\end{abstract}

\section{Introduction}

Weathering (chemical erosion) of continental $\mathrm{Ca}-\mathrm{Mg}$ rich silicates serves as a major sink of atmospheric $\mathrm{CO}_{2}$. However, determining how such weathering has evolved in the past, as a function of climate or tectonic activity, remains a challenge. Filling this gap in our knowledge is essential if we are to understand how global temperature is regulated on geological timescales. The great potential of lithium isotopes for tracing alteration processes has recently been highlighted (see, e.g., review in Burton and Vigier, 2011). Nevertheless, analytical difficulties have limited their use as a marine paleoproxy. Misra and Froelich (2012) and Froelich and Misra (2014) determined the evolution of the lithium isotopic composition of bulk carbonates and planktonic foraminifera over the past $68 \mathrm{My}$. These authors argue that this record reflects ocean-wide variations, and that the $9 \%$ increase of the marine $\delta^{7} \mathrm{Li}$ from the Paleocene to the present (see Fig. 1) can be explained by an increase of river $\delta^{7} \mathrm{Li}$ from $3 \% 00 \mathrm{Ma}$, to $23 \%$ at present. To account for such a rise in riverine $\delta^{7} \mathrm{Li}$, Misra and Froelich (2012) invoke a change of the alteration regime (from a congruent to a weathering-limited regime) and an increase of clay formation (which fractionates $\mathrm{Li}$ isotopes) in mountainous - rapidly eroding - areas. This assertion links the temporal increase in the marine $\delta^{7} \mathrm{Li}$ record to increasing tectonic uplift and mountain building over the course of the Cenozoic. Under this interpretive framework, continental weathering during the early Paleocene $(\approx 60 \mathrm{Ma})$ was characterized principally by high dissolution rates of continental rocks and relatively low rates of clay formation and transport. Such a weathering regime offers a mechanism for producing low $\delta^{7} \mathrm{Li}$ values in rivers, close to that of the 


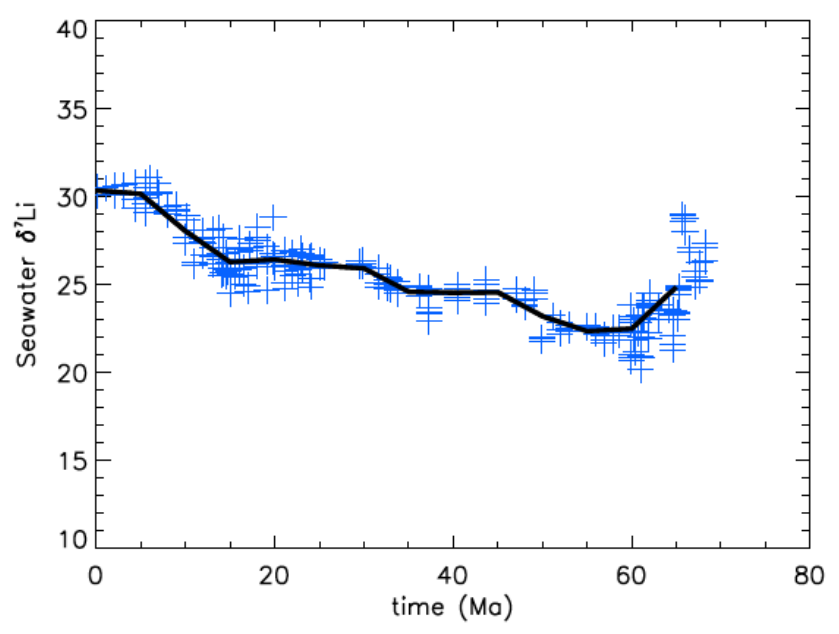

Figure 1. Seawater $\delta^{7} \mathrm{Li}$ (in \%o) as a function of time (blue symbols), modified from Misra and Froelich (2012), assuming that marine foraminifera and carbonates reflect seawater composition. The black line shows a 5 My moving average of the data. All model simulations performed in this study are forced to exactly fit this line.

continental crust, because dissolution is not accompanied by significant Li isotope fractionation. Later in the Cenozoic, as tectonic activity intensifies, incongruent weathering and clay formation is supposed to become more significant, leading to a shift to larger riverine $\delta^{7} \mathrm{Li}$.

However, several lines of evidence call this interpretation of the seawater record into question, in particular the notion that low $\delta^{7} \mathrm{Li}$ values in rivers of the Cretaceous could be sustained by predominately congruent weathering (Wanner et al., 2014). Indeed, a congruency of the weathering process, which would correspond to small rates of clay formation or soil production, at $60 \mathrm{Ma}$ is not supported by the occurrence of thick weathering profiles found at this period of time (e.g., Beauvais and Chardon, 2013; Tavlan et al., 2011; Meshram and Randiv, 2011). In particular, the compilation of laterite formation by Beauvais and Chardon (2013) shows that a major episode of laterite formation is centered around $55 \mathrm{Ma}$ in western Africa, at the time of the climatic optimum (Zachos et al., 2008) and when western Africa was located in the warm and humid convergence zone. Laterite profiles have also been identified at high latitudes during the same time interval. At least four spikes of lateritic formation are recorded between 55 and $48 \mathrm{Ma}$ the cause of it being identified as global warming (e.g., Retallack, 2010, 2014). A compilation of about 80 Ocean Drilling Program or Deep Sea Drilling Project core sites indicate that the deep seawater during the Paleocene exhibited low $\delta^{18} \mathrm{O}$ values, with benthic foraminifera $\delta^{18} \mathrm{O}$ values between 3 and $4 \%$ o lower than at present (Zachos et al., 2001). This feature is interpreted as much warmer climatic conditions, in agreement with recent reconstructions of atmospheric $p \mathrm{CO}_{2}$ at $60 \mathrm{Ma}$, ranging between 400 and 1000 ppmv (Beerling and Royer, 2011).
These conditions have favored the formation of thick weathering profiles, in particular of lateritic regolith mantles rich in kaolinite and/or bauxite. These resistant phases are depleted in major cations playing a key role in the carbon cycle (such as $\mathrm{Ca}$ and $\mathrm{Mg}$ ), but they contain significant amounts of Li. Our compilation of Li levels in kaolinite-rich samples (Table 1) shows that they are - on average - similar to the $\mathrm{Li}$ content estimated for continental crust granite $(22 \pm 4 \mathrm{ppm}$, Teng et al., 2009). They may therefore have played a key role in the continental $\mathrm{Li}$ cycle. Li-containing regoliths provide empirical evidence against the idea that congruent weathering prevails during warm intervals of Earth's history, driving riverine $\delta^{7} \mathrm{Li}$ to values similar to average upper crust.

In this study, we propose a new modeling approach of the seawater record that consists in coupling a simple mathematical description of the carbon and the lithium exospheric budget throughout the Cenozoic. The objective is not to produce an exhaustive study of the impact of each parameter implied in the $\mathrm{Li}$ and the $\mathrm{C}$ cycle, but rather to show that for a given set of parameters consistent with published estimations, there is an alternative solution that can explain the Cenozoic $\delta^{7} \mathrm{Li}$ oceanic variations.

Our model takes into account the changes in Li flux coming from the continents in response to a balance between (1) dissolution rates of continental rocks releasing $\mathrm{Li}$ in water and (2) temporary storage of Li into secondary phases formed in weathering profiles. Since lithium isotopes fractionate during clay mineral accumulation (e.g., Huh et al., 2001; Kisakürek et al., 2004; Rudnick et al., 2004), soil formation rate is expected to drive the $\mathrm{Li}$ isotope composition of rivers. One illustration is that, at present, the mean $\delta^{7} \mathrm{Li}$ value of the continental runoff $(+23 \%$; Huh et al., 1998) is much higher than the average $\delta^{7} \mathrm{Li}$ value estimated for continental crust granite $(+2 \pm 4 \%$, Teng et al., 2009). Since Li isotopes do not fractionate during dissolution, this difference is best explained by isotope fractionation during the formation of secondary phases (Vigier et al., 2009; von Strandmann et al., 2010; Bouchez et al., 2013). Consequently, at present, at the worldwide scale, a significant part of the Li released by continental dissolution is stored in ${ }^{6} \mathrm{Li}$-rich soils, resulting in heavy signatures $\left({ }^{7} \mathrm{Li}\right.$-rich $)$ in rivers. Experimental investigations and soil studies support these findings (e.g., Wimpenny et al., 2010; Vigier et al., 2008; Lemarchand et al., 2010). Thus, we explore how Li storage in soils at the global scale has affected the ocean $\delta^{7} \mathrm{Li}$ value, as well as the potential of ocean $\delta^{7} \mathrm{Li}$ to quantify the balance between physical denudation and chemical alteration and its variation throughout the Cenozoic. 
Table 1. Li concentrations measured in kaolinite (Tardy et al., 1972). These clays contain $0.2 \% \mathrm{MgO}$ (Tardy et al., 1972). On average, the Li level for kaolinite is estimated to be $23 \mathrm{ppm}$. For comparison, average Li content for smectite is found to be $27 \mathrm{ppm}$ (Tardy et al., 1972) and $22 \mathrm{ppm}$ for granite (Teng et al., 2009).

\begin{tabular}{lrl}
\hline Location & Li (ppm) & Reference \\
\hline Côte d'Ivoire & 30 & Tardy et al. (1972) \\
23 & \\
53 & \\
70 & \\
22 & \\
26 & \\
4 & \\
7 & \\
7 & \\
& 8 & \\
& 32 & \\
& 37 & \\
& 5 & \\
& 35 & \\
\hline USA & 20 & Rudnick et al. (2004) \\
\hline Seine Basin (France) & 42 & this study \\
\hline Brazilian Amazon basin & 6.3 & this study \\
& 5.3 & this study \\
& 11.5 & this study \\
& 11.8 & this study \\
\hline Average kaolinite & 23 & \\
\hline
\end{tabular}

\section{Model equations and basics}

\subsection{Seawater isotopic balance}

The two main sources of dissolved lithium to the ocean (oc) are river water (riv) and high-temperature hydrothermal fluids (hyd) (see Huh et al., 1998, and a detailed review in Tomascak, 2004, and in the supplementary material of Misra and Froelich, 2012). The main sink of oceanic lithium is its incorporation into authigenic phases, in particular marine clays which are the marine phases the most enriched in $\mathrm{Li}$ (Chan et al., 2006). The seawater isotopic mass balance can thus be written as

$$
\begin{aligned}
& M_{\mathrm{oc}}^{\mathrm{Li}} \times \mathrm{d} \delta_{\mathrm{oc}} / \mathrm{d} t=F_{\text {riv }}\left(\delta_{\text {riv }}-\delta_{\mathrm{oc}}\right)+F_{\text {hyd }}\left(\delta_{\mathrm{hyd}}-\delta_{\mathrm{oc}}\right) \\
& \quad-F_{\text {clay }}\left(\delta_{\mathrm{oc}}-\Delta_{\mathrm{oc}}-\delta_{\mathrm{oc}}\right),
\end{aligned}
$$

where $F$ is for the $\mathrm{Li}$ flux, and $\delta_{\text {riv }}, \delta_{\mathrm{oc}}$ and $\delta_{\text {hyd }}$ are for the $\delta^{7} \mathrm{Li}$ values of rivers, ocean and hydrothermal fluids, respectively. $\Delta_{\text {oc }}$ represents the absolute value of the fractionation factor of the $\mathrm{Li}$ isotopes during marine secondary phase formation. In the literature, this factor is negative (preferential enrichment of the light ${ }^{6} \mathrm{Li}$ isotope) and ranges between -10 and $-25 \%$ depending on the temperature at which au- thigenic phases are being formed (Chan et al., 1992, 1993; Vigier et al., 2008).

The residence time of $\mathrm{Li}$ in the ocean is equal to $1 \mathrm{mil}-$ lion years. Given that we are exploring the time evolution of its isotopic cycle over the whole Cenozoic (timescale of tens of millions of years), we can assume a steady state for both the elemental (i.e., all the Li carried by rivers and released by hydrothermal activity into the ocean is removed through authigenic clay formation: $\left.F_{\text {riv }}+F_{\text {hyd }}=F_{\text {clay }}\right)$ and isotopic Li cycles. The steady-state hypothesis is only valid for a timescale of several million years (at least 3 times the $\mathrm{Li}$ residence time in the ocean).

Equation (1) becomes

$$
\begin{aligned}
& F_{\text {riv }}\left(\delta_{\text {riv }}-\delta_{\mathrm{oc}}\right)+F_{\text {hyd }}\left(\delta_{\text {hyd }}-\delta_{\mathrm{oc}}\right)+F_{\text {riv }} \times \Delta_{\mathrm{oc}} \\
& \quad+F_{\text {hyd }} \times \Delta_{\mathrm{oc}}=0 .
\end{aligned}
$$

Consequently, we can solve the above equations for $\delta_{\mathrm{oc}}$ :

$\delta_{\text {oc }}=\left(F_{\text {riv }} \delta_{\text {riv }}+F_{\text {hyd }} \delta_{\text {hyd }}+\Delta_{\text {oc }} \times\left(F_{\text {riv }+} F_{\text {hyd }}\right)\right) /\left(F_{\text {riv }+} F_{\text {hyd }}\right)$,

where present-day published values for $F_{\text {riv }}, F_{\text {hyd }}$ and $\Delta_{\mathrm{oc}}$ are reported in Table 2 . We consider that the hydrothermal flux during the Cenozoic decreased slightly as a function of time, following the curve described in Engebretson et al. (1992), based on variations of subduction rates and midocean ridge volume. This trend is currently used in numerical modeling of the global carbon cycle and appears to be consistent with the Cenozoic climatic evolution (Berner, 2004; Lefebvre et al., 2013).

Basically, Eq. (3) has two unknowns: $F_{\text {riv }}^{\mathrm{Li}}$ and $\delta_{\text {riv }}$. In previous studies (Hathorne and James, 2006; Misra and Froelich, 2012), river $\delta^{7} \mathrm{Li}$ has been interpreted as co-varying in a straightforward way with ocean $\delta^{7} \mathrm{Li}$. However, one equation is not enough for two independent unknowns. In contrast to the a priori expectation, the variation of the ocean $\delta^{7} \mathrm{Li}$ composition during the Cenozoic may not reflect riverine $\delta^{7} \mathrm{Li}$ variations in a straightforward way. The reason for this is that it strongly depends on the continental Li flux too, which is likely to have been strongly affected by variation in continental weathering rates during this period of time. One purely theoretical example of the influence of the $\mathrm{Li}$ continental flux is illustrated in Fig. 2. This simulation shows that the 65-0 Ma foraminifera $\delta^{7} \mathrm{Li}$ record (shown in Fig. 1) can still be fitted by imposing a constant river $\delta^{7} \mathrm{Li}$ throughout the Cenozoic, and using parameters values which are consistent with published data (Table 2). We fixed the $\delta_{\text {riv }}\left(\delta^{7} \mathrm{Li}\right.$ in rivers) to its present-day value (23\%o). This is an extreme and unlikely scenario because it does not account for change in the isotope fractionation due to continental weathering. Indeed, the riverine $\delta^{7} \mathrm{Li}$ is expected to vary as a function of the relative importance of dissolution rate and clay formation rate (e.g., Bouchez et al., 2013). However, this simulation shows that by taking into account only the Li ocean budget, the system of equations is under-constrained and it is not possible to calculate the temporal variations of riverine 
Table 2. Parameters used in the model. $\Delta_{\mathrm{oc}}$ and $\Delta_{\text {land }}$ (Li isotope fractionation during secondary phase formation in the ocean and on land, respectively) are chosen from within the published range such that (1) the seawater paleo-variation exactly matches the $5 \mathrm{My}$ fit of the Misra and Froelich (2012) foraminifera data through the Cenozoic (65-0 Ma) (shown in Fig. 1) and (2) at time $t=0$ (present day), both $F_{\text {riv }}(\mathrm{Li})$ and $\delta^{7} \mathrm{Li}_{\text {riv }}$ values must be within the published range (see text for references).

\begin{tabular}{|c|c|c|}
\hline & Published values & Model values \\
\hline$F_{\text {riv }}(\mathrm{Li})$ & $4-12 \times 10^{9} \mathrm{~mol} \mathrm{yr}^{-1}$ & Variable (see figures) \\
\hline$F_{\text {hyd }}(\mathrm{Li})$ & $2-145 \times 10^{9} \mathrm{~mol} \mathrm{yr}^{-1}$ & $5 \times 10^{9} \mathrm{~mol} \mathrm{yr}^{-1}$ \\
\hline$\delta^{7} \mathrm{Li}_{\text {hyd }}$ & $8.5 \pm 1 \%$ & 8 \\
\hline$\delta^{7} \mathrm{Li}_{\mathrm{UCC}}$ & $1.7 \pm 2 \%$ & 1.7 \\
\hline$\delta^{7} \mathrm{Li}_{\text {riv }}$ & $23 \pm 2 \%$ & $\begin{array}{r}\text { Fixed at } 23 \% \\
/ \text { linear/variable } \\
\text { (see figures) }\end{array}$ \\
\hline$\Delta_{\mathrm{oc}}$ & $10-25 \%$ & $14 \%$ \\
\hline$\Delta_{\text {land }}$ & $10-25 \%$ & $23 \%$ \\
\hline $\mathrm{Li} / \mathrm{C}_{\mathrm{hyd}}=1 / k_{2}$ & & $6.67 \times 10^{-4}$ \\
\hline $\begin{array}{l}(\mathrm{Li} /(\mathrm{Ca}+\mathrm{Mg})) \mathrm{UCC} \\
=k_{1}\end{array}$ & & $7.5 \times 10^{-3}$ \\
\hline
\end{tabular}

$\delta^{7} \mathrm{Li}$ without making assumptions about the link between $F_{\text {riv }}^{\mathrm{Li}}$ and $\delta_{\text {riv }}$. It also shows that low seawater $\delta^{7} \mathrm{Li}$, as highlighted by early Eocene foraminifera, can be compatible with a high $\delta^{7} \mathrm{Li}$ value of the riverine flux. Our result shows therefore that low $\delta^{7} \mathrm{Li}$ in the ocean does not systematically imply low river $\delta^{7} \mathrm{Li}$. The temporal variations of the riverine $\mathrm{Li}$ flux also need to be established. In the following, we add constraints to this aspect and the Li cycle by coupling it to the carbon cycle.

\subsection{Walker paleothermostat}

The Walker paleothermostat (Walker et al., 1981) implies that, at the million-year scale, the consumption of carbon by silicate weathering $\left(F_{\text {riv }}^{\mathrm{CO}_{2}}\right)$ closely balances the release by volcanic degassing (assumed to be proportional, on the first order, to the seafloor spreading rate, and hence to the hydrothermal activity) $\left(F_{\text {hyd }}^{\mathrm{CO}_{2}}\right)$, a condition absolutely needed to avoid unrealistic atmospheric $\mathrm{CO}_{2}$ fluctuations (Goddéris and François, 1995; Kump and Arthur, 1997):

$F_{\text {hyd }}^{\mathrm{CO}_{2}}=F_{\text {riv }}^{\mathrm{CO}_{2}}$.

During high-temperature water-rock interactions, $\mathrm{Li}$ is known to be highly mobile, as reflected by the large $\mathrm{Li}$ concentrations found in hydrothermal fluids located in midocean ridges (parts per million level, Chan et al., 1994; Foustoukos et al., 2004; Mottl et al., 2011), and which are $\sim 3$ orders of magnitudes greater than in river water or seawater. Consequently, we consider that the amounts of $\mathrm{Li}$ released by hydrothermal process is proportional to the carbon flux released into the ocean:

$F_{\text {hyd }}^{\mathrm{CO}_{2}}=k_{2} F_{\text {hyd }}^{\mathrm{Li}}$,

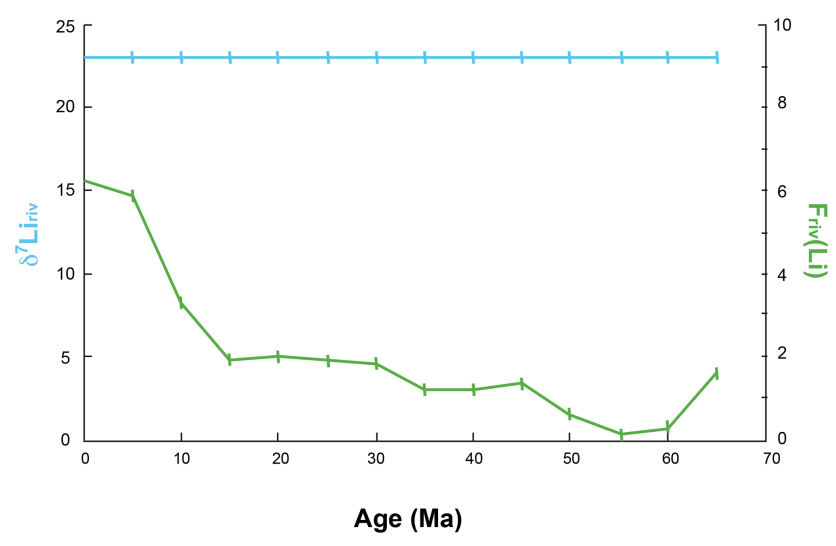

Figure 2. Simulation assuming constant $\delta^{7} \mathrm{Li}_{\text {riv }}$ (in blue) as a function of time. As shown here, the seawater $\delta^{7} \mathrm{Li}$ record presented in Fig. 1 can still be fitted if the flux of river $\mathrm{Li}\left(F_{\text {riv }}\right.$ in $10^{9} \mathrm{~mol} \mathrm{yr}^{-1}$, in green) increased significantly during the same period of time. This example demonstrates the lack of constraints on the steadystate model if only the equation for $\mathrm{Li}$ is considered. In addition, this example shows that river $\delta^{7} \mathrm{Li}$ can display temporal variations that are significantly different from the ocean $\delta^{7} \mathrm{Li}$ record.

with $k_{2}=(\mathrm{C} / \mathrm{Li})$ of hydrothermal fluids (Table 2).

In contrast with hydrothermal conditions, $\mathrm{Li}$ is much less "mobile" on the continents, as reflected by low Li contents in river water (parts per billion level) while granite (the main source of river $\mathrm{Li}$ ) is enriched in $\mathrm{Li}$ compared to oceanic crust. Indeed, first, thermodynamic laws indicate that dissolution rates are lower at lower temperature. Additionally, it is observed that most of the Li carried by rivers to the ocean is mainly located in the particulate load (> 70\%, e.g., Millot et al., 2010), while the dissolved Li represents only a minor portion. This is consistent with the fact that $\mathrm{Li}$ can be significantly incorporated into the structure of secondary minerals, mainly clays. As a consequence, the flux of dissolved Li carried by rivers may not be proportional to the flux of $\mathrm{CO}_{2}$ consumed during the leaching or dissolution of continental mineral phases. The relationship linking the flux of lithium carried by rivers and the flux of atmospheric $\mathrm{CO}_{2}$ consumed by mineral dissolution becomes

$F_{\text {riv }}^{\mathrm{CO}_{2}}=1 / k_{1} \times F_{\text {diss }}^{\mathrm{Li}}=\left(F_{\text {riv }}^{\mathrm{Li}}+F_{\text {sp }}^{\mathrm{Li}}\right) / k_{1}$.

$F_{\text {riv }}^{\mathrm{Li}}$ and $F_{\mathrm{sp}}^{\mathrm{Li}}$ being the flux of lithium in river water and in secondary phases, respectively, and $F_{\text {diss }}^{\mathrm{Li}}$ the flux of Li released into continental waters during the dissolution of continental rocks $\left(F_{\text {riv }}^{\mathrm{Li}}=F_{\mathrm{diss}}^{\mathrm{Li}}-F_{\mathrm{sp}}^{\mathrm{Li}}\right) . k_{1}$ is calculated assuming that dissolution of continental rocks release $\mathrm{Li}, \mathrm{Mg}$ and $\mathrm{Ca}$ congruently. Also, we consider that $1 \mathrm{~mol}$ of atmospheric $\mathrm{CO}_{2}$ is consumed by the dissolution of $1 \mathrm{~mol}$ of $\mathrm{Ca}+\mathrm{Mg}$ present in continental rocks (accounting for the subsequent carbonate precipitation in the ocean) (Berner, 2004). Consequently, $k_{1}=\mathrm{Li}_{\mathrm{UCC}} /(\mathrm{Ca}+\mathrm{Mg})_{\mathrm{UCC}}$ (UCC being the upper continental crust, Table 2). 
If present-day conditions reflect a recent disequilibrium due to the last glaciation (Vance et al., 2009), at the Cenozoic timescale, the formation of thick weathering profiles with significant residence times $(>0.5 \mathrm{My})$ are likely to have impacted the $\mathrm{Li}$ cycle. We assume that most of secondary phases present in these profiles are largely depleted in cations, in particular in $\mathrm{Ca}$ and $\mathrm{Mg}$, and therefore do not significantly affect the carbon budget. This is a first-order approximation. Indeed, laterite in which the largely dominant clay phase is $\mathrm{Ca}+\mathrm{Mg}$ free kaolinite, covers only $30 \%$ of the continental surfaces. However, owing to their thickness, they constitute about $85 \%$ of the global continental pedogenic cover (Nahon, 2003), supporting the above assumption.

Combining Eqs. (4), (5) and (6) we obtain the following relationship:

$F_{\text {riv }}^{\mathrm{Li}}=k_{1} \times k_{2} F_{\text {hyd }}^{\mathrm{Li}}-F_{\text {sp }}^{\mathrm{Li}}$,

where the flux of riverine $\mathrm{Li}$ is a function of both the hydrothermal flux and of the secondary phase formation rate on the continents.

\subsection{Riverine $\delta^{7} \mathbf{L i}$}

All published studies indicate the existence of a strong isotope fractionation during the formation of secondary phases, such as clays or Fe oxides, always in favor of the light isotope $\left({ }^{6} \mathrm{Li}\right)$. At periods when the soil production increased in the past due to the increase rate of secondary phase formation, we therefore expect that the $\delta^{7} \mathrm{Li}$ of river water increases, since more ${ }^{6} \mathrm{Li}$ is incorporated and stored in soils. In fact, the riverine $\delta^{7} \mathrm{Li}$ is the result of the competition (e.g., Bouchez et al., 2013; Vigier et al., 2009) between the isotopically congruent dissolution of fresh bedrock and the precipitation of secondary phases with an isotope fractionation $\Delta_{\text {land }}$ (Table 2), such that

$F_{\text {riv }}^{\mathrm{Li}} \delta_{\text {riv }}=\delta_{\mathrm{UCC}} \times F_{\text {diss }}^{\mathrm{Li}}-F_{\mathrm{sp}}^{\mathrm{Li}} \times\left(\delta_{\text {riv }}-\Delta_{\text {land }}\right)$,

with $\delta_{\mathrm{UCC}}$ being the average $\delta^{7} \mathrm{Li}$ value estimated for the upper continental crust (Table 2).

Given that $F_{\text {diss }}^{\mathrm{Li}}=F_{\text {riv }}^{\mathrm{Li}}+F_{\text {sp }}^{\mathrm{Li}}$, Eq. (8) becomes

$\delta_{\text {riv }}=\delta_{\mathrm{UCC}}+\left(F_{\mathrm{sp}}^{\mathrm{Li}} \Delta_{\text {land }}\right) /\left(F_{\text {riv }}^{\mathrm{Li}}+F_{\mathrm{sp}}^{\mathrm{Li}}\right)$.

This equation states that if $F_{\mathrm{sp}}^{\mathrm{Li}}=0$, then $\delta_{\text {riv }}=\delta_{\mathrm{UCC}}$. Otherwise, $\delta_{\text {riv }}$ is higher than $\delta_{\mathrm{UCC}}$. To date, the published values of $\delta^{7} \mathrm{Li}$ of most rivers (e.g., Huh et al., 1998; Millot et al., 2010; Kisakürek et al., 2004) are significantly greater than the $\delta^{7} \mathrm{Li}$ estimated for UCC ( $2 \%$, Teng et al., 2009), and thus are consistent with Eq. (9).

\subsection{Method for solving the model}

We assume that the foraminifera $\delta^{7} \mathrm{Li}$ reflect the ocean $\delta^{7} \mathrm{Li}$, as assumed in Misra and Froelich (2012) and in Hathorne and James (2006). We consider that the potential vital effects, responsible for changes of $\mathrm{Li}$ isotope fractionation during foraminifera growth, may explain some observed rapid $(<0.5 \mathrm{My})$ changes of foraminifera $\mathrm{Li}$ isotope compositions, but we do not take into account these effects since the model aims at working at the multi-million-year scale only. A moving average of the oceanic lithium isotopic data is calculated, with a window width of 5 million years, since the isotopic steady state is valid for a timescale of at least 3 times the $\mathrm{Li}$ residence time in the ocean (see Fig. 1). This data smoothing therefore ensures the validity of the steady-state hypothesis and removes all short-term fluctuations potentially related to vital effects.

The equations describing the seawater isotopic budget (Eq. 3), the paleothermostat (Eq. 7) and the riverine isotopic budget (Eq. 9) define a system of equations where the unknowns are the riverine $\mathrm{Li}$ flux as a function of time $\left(F_{\text {riv }}^{\mathrm{Li}}\right)$, the storage flux of $\mathrm{Li}$ in soils $\left(F_{\mathrm{sp}}^{\mathrm{Li}}\right)$ and the riverine $\delta^{7} \mathrm{Li}$ $\left(\delta_{\text {riv }}\right)$. It can be reduced to the following quadratic equation:

$A_{1}\left(F_{\text {riv }}^{\mathrm{Li}}\right)^{2}+\left(\delta_{\mathrm{oc}}-\Delta_{\mathrm{oc}}-\delta_{\mathrm{UCC}}-\Delta_{\mathrm{land}}\right) F_{\text {riv }}^{\mathrm{Li}}-A_{2}=0$,

where $A_{1}$ and $A_{2}$ are equal to

$$
\begin{aligned}
& A_{1}=\Delta_{\text {land }} /\left(k_{1} k_{2} F_{\mathrm{Hyd}}^{\mathrm{Li}}\right), \\
& A_{2}=F_{\mathrm{Hyd}}^{\mathrm{Li}}\left(\delta_{\text {hyd }}-\delta_{\mathrm{oc}}+\Delta_{\mathrm{oc}}\right) .
\end{aligned}
$$

The values for the various parameters used in the model are described in Table 2. As long as the discriminant of Eq. (10) is strictly positive, Eq. (10) has two solutions for $F_{\text {riv }}^{\mathrm{Li}}$. This means that two radically different histories of $F_{\text {riv }}^{\mathrm{Li}}$ can both explain the rise of the $\mathrm{Li}$ isotopic composition of seawater.

\subsection{Comparison with other modeling methods}

Recently, two modelings of the Cenozoic $\delta^{7} \mathrm{Li}$ variations, different from Misra and Froelich (2012) and Froelich and Misra (2014) have been proposed. Wanner et al. (2014) focused on a reactive transport model in order to simulate the $\mathrm{Li}$ isotopic composition and content of continental waters. Weathering reactions by sub-surface waters are simulated, considering a prescribed thick regolith which already contains altered material (kaolinite and goethite), above fresh granite. Kinetic reactions based on transition state theory are used for calculating both the dissolution and precipitation of mineral phases. River water chemistry is then considered to be a simple dilution of these sub-surface waters having reacted with previously formed profiles. Overall, the Wanner et al. (2014) model is designed to simulate finely the time evolution of an already existing regolith profile and its impact on the riverine Li content and isotopic composition. As acknowledged by the authors, the fit of the Cenozoic oceanic $\delta^{7} \mathrm{Li}$ curve cannot be computed as it requires the accurate knowledge of the Cenozoic climate and runoff variations in order to calculate the $\mathrm{Li}$ flux to the ocean as well as its isotopic composition. The Wanner et al. (2014) model is a 
process-based model, but at this stage, it cannot account for global budget.

Li and West (2014) proposed 12 different simulations for fitting the Cenozoic ocean $\delta^{7} \mathrm{Li}$, focusing their effort on potential variations of the oceanic Li sink and how this could have affected the ocean $\delta^{7} \mathrm{Li}$. They consider that the two major sinks of ocean $\mathrm{Li}$ are marine authigenic aluminosilicate clays (during reverse weathering, at low temperature) and removal into oceanic crust during its alteration by circulating fluids of moderate-to-high temperatures. Both sinks are considered to be associated with a constant isotope fractionation factor throughout the Cenozoic, but a varying proportion of both is considered to influence the $\mathrm{Li}$ and $\delta^{7} \mathrm{Li}$ removal flux. Then, a steady-state equation is applied to the ocean, identical to the one used here, and different scenarios are tested to explore the impact of the mathematical formulation of the oceanic Li sinks. Changes of river $\mathrm{Li}$ flux are assumed to be dependent on the chemical weathering fluxes calculated by another model (Li and Elderfield, 2013), or following the isotope balance method developed by Bouchez et al. (2013). Hydrothermal $\mathrm{Li}$ is estimated from the reconstruction of spreading rate (Muller et al., 2008; Rowley, 2002). No direct coupling with the carbon cycle is made.

At this stage, it is important to underline that by coupling $\mathrm{Li}$ and $\mathrm{C}$ budgets, the solving of our model equations does not require additional or independent assumptions for the continental fluxes (dissolved and particulate) during the Cenozoic. Furthermore, our model is based on budget equations only (for $\mathrm{Li}$ and $\mathrm{C}$ ), and does not include any assumption on the dependence of the fluxes on environmental conditions. The solid Earth degassing is extracted from Egenbretson (1992). Although more recent reconstructions have been published, it has been shown recently that the Engebretson's curve is in good agreement with the Cenozoic climate history (itself reconstructed using a coupled 3-D climate-carbon model, see Lefebvre et al., 2013). The precise Cenozoic history of the solid Earth degassing weakly influences our results.

\section{Results and discussion}

\subsection{Paleo-variations of continental weathering}

Two solutions have thus been found for the Cenozoic (represented in Fig. 3a and b). The first solution (Fig. 3a) implies an increase of the riverine $\delta^{7} \mathrm{Li}$ over the Cenozoic, associated with a decrease of riverine Li flux with time. This first solution is close to the scenario described in details by Misra and Froelich (2012), arguing for an increasing contribution of orogenesis on silicate dissolution, clay formation and $\mathrm{CO}_{2}$ consumption towards recent time. In this scenario, sequestration of lithium in clays increased from the past towards the present day.
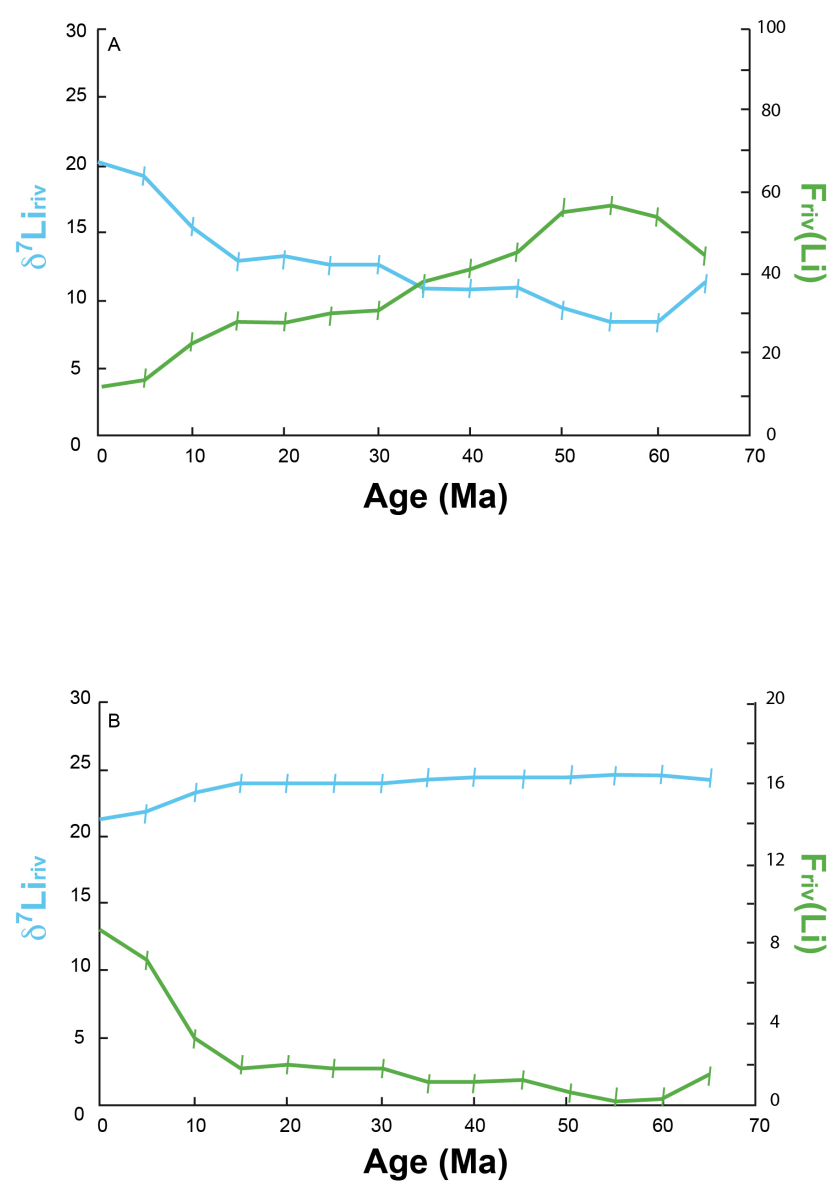

Figure 3. The two solutions of the model described in the text that can both explain the seawater record (see Eqs. (3-12), and Table 2) $F_{\text {riv }}$ is in $10^{9} \mathrm{~mol} \mathrm{yr}^{-1}$ (in green). (a) This solution is consistent with calculations performed by Misra and Froelich (2012) since low $\delta^{7} \mathrm{Li}$ values are found for $60 \mathrm{Ma}$ rivers which then increased as a function of time (in blue). (b) A second solution is also possible, using exactly the same set of parameters. In this case, river $\delta^{7} \mathrm{Li}$ has decreased as a function of time while the Li river flux has increased.

Our model results demonstrate that a second scenario can also explain the Cenozoic $\mathrm{Li}$ isotope record, and we will focus on this in the following because the first scenario was already investigated in details by Misra and Froelich (2012) and by $\mathrm{Li}$ and West (2014). Figure $3 \mathrm{~b}$ shows that the $\delta^{7} \mathrm{Li}$ paleo-record can be due to an increase of the riverine Li flux through the Cenozoic. As illustrated in Fig. 4, this increase is not due to an increase in the dissolution rate of the silicate lithologies, but is mostly due to the decrease of Li storage in secondary phases. Most Li-rich secondary phases are considered to be formed within soil and lateritic profiles, and even if some have the time to be formed during the river transport, this fraction is likely minor compared to the formation of thick soils and kaolinite-rich laterite. Therefore, we consider that most of the Li storage during silicate alteration occur in soils. 


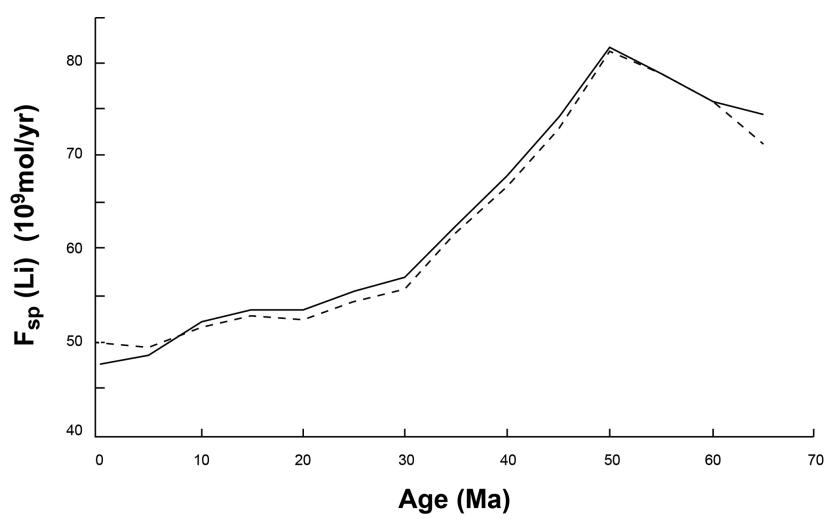

Figure 4. Flux of lithium incorporated into continental secondary phases as a function of time $\left(F_{\mathrm{sp}}\right)$, see Eq. (6), following solution no. 2 of the modeling (shown in Fig. 3b). Comparison is made using a linear evolution for river $\delta^{7} \mathrm{Li}$ as a function of time, from 15 (at $65 \mathrm{Ma}$ ) to $23 \%$ (present day) (dashed line).

In order to test the robustness of our result, we performed two different simulations, using (1) the whole set of equations (for both $\mathrm{C}$ and $\mathrm{Li}$, see Sect. 2) and (2) an imposed variation of $\delta_{\text {riv }}$ that is arbitrarily forced to increase linearly from $15 \%$ at $65 \mathrm{Ma}$ to $23 \%$, its present-day value (in that case, only the Li budget is solved, not C). Both simulations lead to similar trends, where $\mathrm{Li}_{\text {soil }}$ decrease as a function of time (see Fig. 4). This strongly suggests the robustness of the observed decrease, and also confirms that the Li isotope composition of rivers plays only a minor role in the ocean isotopic variation. Overall, these results show that soil Li storage was high from 65 to $50 \mathrm{Ma}$, and then decreased continuously until its stabilization at about $20 \mathrm{Ma}$ (Fig. 4).

In order to be more quantitative, check the consistency of these results and compare them to other proxies, we estimated the corresponding soil formation rates, assuming a Li concentration of $25 \mathrm{ppm}$, which corresponds to an average soil Li concentration, including data shown in Table 1. This is a first approximation because secondary phase formation rate (calculated from Li data) may not strictly correspond to soil formation rate. Also, the estimated average soil Li content may be associated with a large error, as there are currently only few data. It may also have varied as a function of time, although this is not supported by the relative narrow range of $\mathrm{Li}$ concentration of the most abundant clays. Nevertheless, this assumption allows us to assess if the order of magnitude for the fluxes extracted from our model makes sense. Also, a compilation of Li contents for the most abundant low-T continental clays show that the average $\mathrm{Li}$ value is not so different from one type of clay to another (Tardy et al., 1972; Table 1). During the Cenozoic, we thus estimate that soil formation rate ranged from $2.2 \times 10^{19} \mathrm{~kg} \mathrm{My}^{-1}$ to a present-day value of $1.3 \times 10^{19} \mathrm{~kg} \mathrm{My}^{-1}$, i.e., $2.2 \times 10^{10}$ to $1.3 \times 10^{10} \mathrm{tyr}^{-1}$. For comparison, Syvitski et al. (2003) estimated a present-day global physical denudation rate of
$2 \times 10^{10} \mathrm{tyr}^{-1}$. The Syvitski denudation rate includes secondary phases and fresh minerals but the most important here is that both orders of magnitude are similar, and not totally at odds. Reconstitution of paleo-denudation rates during the Cenozoic is controversial (e.g., Willenbring and von Blanckenburg, 2010), but given the uncertainties typical of global-scale estimations, it is worth noting that the calculated soil formation falls quite close (less than an order of magnitude difference) to the independent global denudation estimate, indicating that our calculations - based on $\mathrm{C}$ and $\mathrm{Li}$ cycles and published values for corresponding parameters - make sense. Considering the uncertainties for both estimations, a strict comparison between both numbers (physical and chemical erosion rates) in order to determine if the erosion regime has globally remained close to steady state (where denudation rates and soil production rates are equal) during the Cenozoic does not appear to be relevant yet.

\subsection{Assessing the role of climate}

Except for the last few million years, the paleoreconstruction of soil formation rate during the Cenozoic is remarkably parallel to the $\delta^{18} \mathrm{O}$ values measured in benthic foraminifera (Zachos et al., 2001, see Fig. 5b). This strongly suggests a major role of climate in soil development at the global scale. When the climate gets cooler, soil formation rates decrease. A potential increase of weathering rates due to orogenesis and mountain building during the Cenozoic is therefore not able to compensate for the role of temperature. In the open debate concerning the controls of continental chemical erosion rates at the global scale over the Cenozoic, $\mathrm{Li}$ isotopes yield good evidence for the predominance of climate over mechanical erosion. Specifically, the fact that soil formation rates predicted by the model parallel the global benthic oxygen isotope record shows that the impact of orogenesis is not strong enough to counterbalance the impact of temperature decrease.

More closely inspecting the comparison between soil formation rate, $\delta^{18} \mathrm{O}$ and $p \mathrm{CO}_{2}$ paleo-variations reveals four remarkable features:

1. High soil formation rates during the Paleocene and Early Eocene coincide with high $p \mathrm{CO}_{2}$ estimations (Beerling and Royer, 2011) as well as low foraminifera $\delta^{18} \mathrm{O}$ values. This strongly suggests that weathering rates were high because of climatic conditions favoring both dissolution of silicate rocks and formation of secondary minerals and laterites. In order to explain the high riverine $\delta^{7} \mathrm{Li}$ values associated with low $\mathrm{Li}$ flux at this period of time (see Fig. 3b), our budget equations require a massive transformation of fresh rocks into regolith. High soil production rates also requires high weathering rates, consistent with large estimated atmospheric $p \mathrm{CO}_{2}$ levels. This intense weathering leads to worldwide production of thick lateritic profiles, which is evidenced in many parts of the world (e.g., Beauvais 

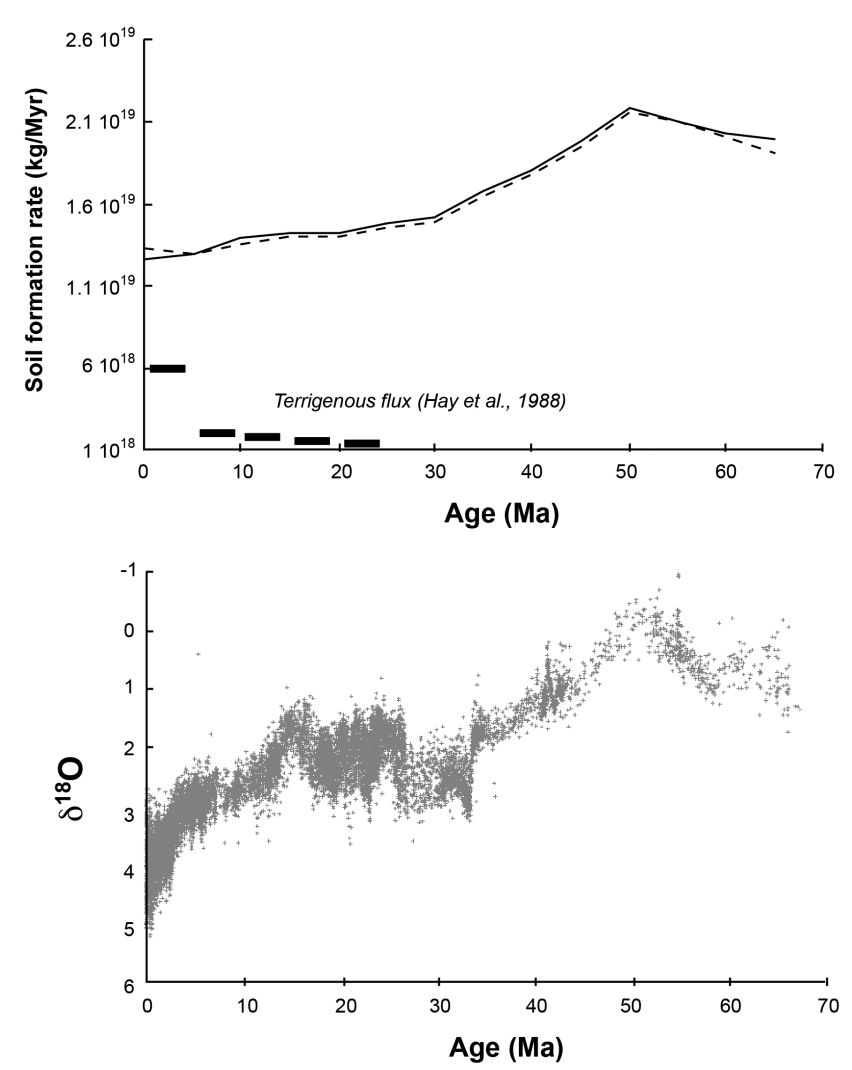

Figure 5. (a) Evolution of soil formation rate as a function of time deduced from the modeling of Li data and assuming that most secondary phases are formed in soils (see text for more details). A published estimation of evolution of terrigenous flux is shown for comparison (same unit). (b) Variation of $\delta^{18} \mathrm{O}$ of benthic foraminifera as a function of time (compilation from Zachos et al., 2001).

and Chardon, 2013; Retallack, 2010; Tabor and Yapp, 2005; Robert and Kennett, 1992).

2. A sharp decrease of soil formation rates coeval with a sharp increase in foraminifera $\delta^{18} \mathrm{O}$ during the Eocene until the beginning of the Oligocene. This co-variation suggests a predominant role on climate cooling in continental soil production. However, during this period of time, we cannot exclude a global thinning of soils by mountain building and orogenesis. Steeper slopes, higher relief and increasing impact of landslide contribute significantly to reduce the world average soil thickness.

3. A stabilization of the weathering rates between 30 and $10 \mathrm{Ma}$, which matches the plateaus exhibited by $p \mathrm{CO}_{2}$ (not shown here, but see Beerling and Royer, 2011) and $\delta^{18} \mathrm{O}$ proxies.

4. A decoupling between soil formation rate, benthic foraminifera $\delta^{18} \mathrm{O}$ and physical denudation rate during the Quaternary period. Indeed, both soil formation

rates and $p \mathrm{CO}_{2}$ estimates remain globally stable during this period. However, foraminifera $\delta^{18} \mathrm{O}$ and denudation rates (e.g., Hay et al., 1988) show significant variations, consistent with the development of a cool climate and glaciations. Reconstructions of ${ }^{10} \mathrm{Be} /{ }^{9} \mathrm{Be}$ in the ocean also suggest a constancy of the continental weathering rates for the last 5-10 My and have questioned the relationship between physical and chemical erosion rates (Willenbring and von Blanckenburg, 2010). Our results suggest that the recent climatic variations were not strong enough to affect the Li cycle, as evidenced by constant foraminifera $\delta^{7} \mathrm{Li}$ value during the last $5 \mathrm{My}$. The other possibility is that the present-day residence time of $\mathrm{Li}$ in the ocean is underestimated and the chemical - and potentially physical - disturbances related to Quaternary glaciations did not have time yet to significant affect its oceanic budget.

\subsection{Open questions}

Our result for the Paleocene/Eocene differs from previous modelings in two ways: first, the low ocean $\delta^{7} \mathrm{Li}$ values at the Paleocene/Eocene boundary may not necessarily require low riverine $\delta^{7} \mathrm{Li}$ values, as previously considered in Wanner et al. (2014), in Misra and Froelich (2012) and in Li and West (2014). Secondly, at a period of time where weathering profiles are abundant and thick, the Wanner et al. (2014) reactive transport model shows that low riverine $\delta^{7} \mathrm{Li}$ such as observed at the Paleocene/Eocene boundary can be explained by predominant dissolution of previously formed secondary phases occurring in pre-formed thick regoliths (rich in kaolinite and goethite) (see Sect. 2.5). The inverse relationship between regolith thickness and riverine $\delta^{7} \mathrm{Li}$ arises from a longer residence time of water in contact with depleted secondary phases during periods characterized by weak tectonic activity and low physical erosion rates. In contrast, our model, which is based on budget equations only, implies that the formation of secondary phases from fresh bedrock produce an increase of river $\delta^{7} \mathrm{Li}$ because ${ }^{6} \mathrm{Li}$ is preferentially stored in regolith in formation.

Future studies should merge both methods such that the transformation of the fresh bedrock into regolith and the building of thick weathering profiles can be accounted for, as well as the reactivity of the regolith itself.

The amount of published $\mathrm{Li}$ concentrations in various types of clay is still too limited to estimate precisely the $\mathrm{Li}$ mobility at the continental scale. At present, river particles carry more than $80 \%$ of the river total Li flux (calculation based on discharge and fluxes published by Gaillardet et al., 1999 and published average $\mathrm{Li}$ concentration for river water and suspended particles, Huh et al., 1998, 2001; Kisakürek et al., 2005; Millot et al., 2010; Dellinger et al., 2014). At $55 \mathrm{Ma}$, the Li storage in soils is very close to $100 \%$ (following solution B). This corresponds precisely to the longest and one of the most intense weathering events of the Cenozoic in 
western Africa (Beauvais and Chardon, 2013), and probably elsewhere in the world (Rettalack, 2010). Conversely, case A predicts that only $20 \%$ of $\mathrm{Li}$ is retained during this event. Constraining more precisely the role of Li-rich kaolinite formation in soils and laterites would certainly add precious information to the debate. A recent study of Hawaiian basaltic soil chronosequence (Ryu et al., 2014) shows that $\mathrm{Li}$ is retained at $100 \%$ in soil layers rich in kaolinite, which further supports their critical role, but more investigation at larger scale is now required.

In our modeling, the hydrothermal carbon flux is assumed to be strictly compensated for by continental silicate weathering. The potential role of other sources/sinks of carbon has been neglected at this stage, in particular the influence of metamorphism and of organic matter burial. Indeed, disequilibria in the organic carbon sub-cycle may alter the ratio between the total $\mathrm{CO}_{2}$ consumption by continental silicate weathering and the $\mathrm{CO}_{2}$ released hydrothermal activity. In the case of the strontium cycle for instance, it is well known that such additional processes may produce non-negligible fluctuations of the oceanic isotopic composition (Goddéris and François, 1995). In the case of the Li cycle, these processes are not expected to influence directly the $\mathrm{Li}$ fluxes and their isotope signatures. However, changes in carbon fluxes can potentially produce alteration of the $\mathrm{Li}$ isotopic composition of the ocean. This is an important field for future investigation. The objective here was to decipher the first-order control factors of the time evolution of the Li cycle. The calculated scenarios must be seen as a background history, neglecting at this stage processes that could modulate the model output around the proposed long-term averaged evolution.

Although our model depends on the Li content of the continental silicate rock being altered, there is no constraint on how these contents may fluctuate globally during the Cenozoic. Determining how each rock type (basalt, granite, shale) contributes to the global weathering flux, according to change in climate, vegetation and tectonic settings, is beyond the capability of our simple model. This aspect is currently explored with coupled 3-D climate/biogeochemical models (Taylor et al., 2012; Lefebvre et al., 2013), showing for example that the position of India relative to the tropical belt strongly controls the alteration of the Deccan Traps lava flows. Exploring the impact of this on the lithium cycle is a task for the future.

\section{Conclusions}

We provide a new approach for modeling the seawater $\delta^{7} \mathrm{Li}$ record, preserved in marine foraminifera and carbonate records (Misra and Froelich, 2012). The Li cycle includes several fluxes of importance for the carbon cycle (and hence for the climatic evolution), including continental weathering and hydrothermal water-rock interactions. For this reason, we have combined the $\mathrm{C}$ and the $\mathrm{Li}$ cycles so that our pro- posed reconstruction of the Cenozoic Li cycle is compatible with the required stability of the exospheric carbon cycle at the geological timescale (Walker et al., 1981). Results are consistent with the current knowledge of the behavior of $\mathrm{Li}$ isotopes during continental weathering (1) in terms of isotope fractionation during dissolution and clay formation and (2) in term of present-day river flux and river $\delta^{7} \mathrm{Li}$.

We show that the paleo-variation of the ocean $\delta^{7} \mathrm{Li}$ throughout the Cenozoic, can be explained by significant $\mathrm{Li}$ stored on the continents during the Paleocene and Eocene, likely in secondary phases which are Li-rich, such as phyllosilicates and oxides. Then this storage flux globally decreases towards the present day, while the export to the ocean by weathering increases. This storage follows indexes recording the climate evolution during the Cenozoic, such as foraminifera $\delta^{18} \mathrm{O}$ and $p \mathrm{CO}_{2}$ reconstructions. More effort is now needed in order to reduce the uncertainties associated with the Li cycle, and better deconvolve the role of erosion from the one of climate during specific periods of the Cenozoic.

Acknowledgements. We would like to thank Thierry Allard for discussions on laterite and kaolinite samples. Chris Wanner, Paul Tomascak and an anonymous reviewer are thanked for their helpful comments. The associate editors Appy Sluijs and Andrea Dutton are thanked for constructive remarks and editorial handling of the manuscript. Natascha Töpfer is thanked for her editorial support. This work was funded by an INSU-CNRS project.

Edited by: A. Sluijs

\section{References}

Beauvais, A. and Chardon, D.: Modes, tempo, and spatial variability of Cenozoic cratonic denudation: The West African example, Geochem. Geophys. Geosyst., 14, 1590-1608, doi:10.1002/ggge.20093, 2013.

Beerling, D. J. and Royer, D. R.: Convergent Cenozoic $\mathrm{CO}_{2}$ history, Nature Geosci., 4, 418-420, doi:10.1038/ngeo1186, 2011.

Berner, R. A.: The Phanerozoic carbon cycle: $\mathrm{CO}_{2}$ and $\mathrm{O}_{2}$, Oxford University Press, 160 pp., 2004

Bouchez, J., Von Blankenburg, F., and Schuessler, J. A.: Modeling novel stable isotope ratios in the weathering zone, Am. J. Science, 313, 267-308, doi:10.2475/04.2013.01, 2013.

Burton, K. W. and Vigier, N.: Lithium isotopes as tracers in marine and terrestrial environments, Handbook of Environmental Isotope Geochemistry, edited by: Baskaran, M., 41-61, Springer, Berlin, 2011

Chan, L.-H., Edmond, J. M., Thompson, G. and Gillis, K.: Lithium isotopic composition of submarine basalts: implications for the lithium cycle to the ocean, Earth Planet. Sci. Lett., 108, 151-160, 1992.

Chan, L.-H., Edmond, J. M., and Thompson, G.: A lithiumisotope study of hot springs and metabasalts from mid ocean ridge hydrothermal systems, J. Geophys. Res., 98, 9653-9659, 1993. 
Chan, L.-H., Gieskes, J. M., You, C.-F., and Edmond, J. M.: Lithium isotope geochemistry of sediments and hydrothermal fluids of the Guaymas Basin, Gulf of California, Geochim. Cosmochim. Acta., 58, 4443-4454, 1994.

Chan, L.-H., Leeman, W. P., and Plank, T.: Lithium isotopic composition of marine sediments, Geochem. Geophys. Geosyst., 7, Q06005, doi:10.1029/2005GC001202, 2006.

Dellinger, M., Gaillardet, J., Bouchez, J., Calmels, D., Galy, V., Hilton, R. G., Louvat, P., and France-Lanord, C.: Lithium isotopes in large rivers reveal the cannibalistic nature of modern continental weathering and erosion, Earth Planet. Sci. Lett., 401, 359-372, 2014.

Engebretson, D. C., Kelley, K. P., Cashman, H. J., and Richard, M. A.: 180 million years of subduction, GSA Today, 2, 9-100, 1992.

Froelich, F. and Misra, S.: Was the Late Paleocene-Early Eocene Hot Because Earth Was Flat? An Ocean Lithium Isotope View of Mountain Building, Continental Weathering, Carbon Dioxide, and Earth's Cenozoic Climate, Oceanography, 27, 36-49, 2014.

Foustoukos, D. I., James, R. H., Berndt, M. E., and Seyfried Jr., W. E.: Lithium isotopic systematic of hydrothermal vent fluids at the Main Endeavour Field, Northern Juan de Fuca Ridge, Chem. Geol., 212, 17-26, 2004.

Goddéris, Y. and Francois, L. M.: The Cenozoic evolution of the strontium and carbon cycles: relative importance of continental erosion and mantle exchanges, Chem. Geol., 126, 169-190, 1995.

Hathorne, E. C. and James, R. H.: Temporal record of lithium in seawater: A tracer for silicate weathering?, Earth Planet. Sci. Lett., 246, 393-406, 2006.

Hay, W. W., Sloan, J. L. I., and Wold, C. N.: The mass/age distribution of sediments on the ocean floor and the global rate of loss of sediment, J. Geophys. Res., 93, 14933-14940, 1988.

Huh, Y., Chan, L.-H., Zhang, L., and Edmond, J. M.: Lithium and its isotopes in major world rivers: Implications for weathering and the oceanic budget, Geochim. Cosmochim. Acta, 62, 2039-2051, 1998.

Huh, Y., Chan, L.-H., and Edmond, J. M.: Lithium isotopes as a probe of weathering processes: Orinoco River, Earth Planet. Sci. Lett., 194, 189-199, 2001.

Kisakürek, B., Widdowson, M., and James, R. H.: Behaviour of Li isotopes during continental weathering: the Bidar laterite profile, India. Chem. Geol., 212, 27-44, 2004.

Kisakürek, B., James, R. H., and Harris, N. B. W.: Li and $\delta^{7} \mathrm{Li}$ in Himalayan rivers: Proxies for silicate weathering?, Earth Planet. Sci. Lett., 237, 387-401, 2005.

Kump, L. R. and Arthur, M. A.: Global chemical erosion during the Cenozoic: Weatherability balances the budgets, in: Tectonics Uplift and Climate Change, edited by: Ruddiman, W., Plenum Press., N.Y., 399-426, 1997.

Lefebvre, V., Donnadieu, Y., Goddéris, Y., Fluteau, F., and HubertThéou, L.: Was the Antarctic glaciation delayed by a high degassing rate during the early Cenozoic?, Earth Planet. Sci. Lett., 371, 203-211, 2013.

Lemarchand, E., Chabaux, F., Vigier, N., Millot, R., and Pierret, MC.: Lithium isotope systematics in a forested granitic catchment (Strengbach, Vosges Mountains, France), Geochim. Cosmochim. Acta, 74, 4612-4628, 2010.
Li, G. and Elderfield, H.: Evolution of carbon cycle over the past 100 million years, Geochim. Cosmochim. Acta, 103, 11-25, 2013.

Li, G.-J. and West, A. J.: Evolution of Cenozoic seawater lithium isotopes: coupling of global denudation regime and shifting seawater sinks, Earth Planet. Sci. Lett., 401, 284-293, doi:10.1016/j.eps1.2014.06.011, 2014.

Meshram, R. R. and Randive, K. R.: Geochemical study of laterites of the Jamnagar district, Gujarat, India: Implications on parent rock, mineralogy and tectonics, J. Asian Earth Sci., 42, 12711287, doi:10.1016/j.jseaes.2011.07.014, 2011.

Millot, R., Vigier, N., and Gaillardet, J.: Behaviour of lithium and its isotopes during weathering in the Mackenzie Basin, Canada, Geochim. Cosmochim. Acta, 74, 3897-3912, 2010.

Misra, S. and Froelich, P. N.: Lithium Isotope History of Cenozoic Seawater: Changes in Silicate Weathering and Reverse Weathering, Science, 335, 818-823, 2012.

Mottl, M. J., Seewald, J. S., Wheat, C. J., Tivey, M. K., Michael, P. J., Proskurowski, G., McCollom, T. M., Reeves, E., Sharkey, J., You, C. F., Chan, L. H., and Pichler, T.: Chemistry of hot springs along the Eastern Lau Spreading Center, Geochim. Cosmochim. Acta, 75, 1013-1038, 2011.

Muller, R. D., Sdrolias, M., Gaina, C., and Roest, W.: Age, spreading rates, and spreading asymmetry of the world's ocean crust, Geochem. Geophys. Geosys., 9, Q04006, doi:10.1029/2007GC001743, 2008.

Nahon, D.: Alterations dans la zone tropicale. Signification à travers les mécanismes anciens et/ou encore actuels C.R., Geoscience, 335, 1109-1119, 2003.

Retallack, G. J.: Laterization and bauxitization events, Econ. Geol., 105, 655-667, 2010.

Retallack, G. J.: Cool-climate or warm-spike lateritic bauxites at high latitudes?, J. Geol., 116, 558-570, 2014.

Robert, C. and Kennett, J. P.: Paleocene and Eocene kaolinite distribution in the South Atlantic and Southern Ocean: Antarctic climatic and paleoceanographic implications, Mar. Geol., 103, 99-101, 1992.

Rowley, D. B.: Rate of plate creation and destruction: $180 \mathrm{Ma}$ to present, GSA Bull., 114, 927-933, 2002.

Rudnick, R. L., Tomascak, P. B., Njoa, H. B., and Gardnerb, L. R.: Extreme lithium isotopic fractionation during continental weathering revealed in saprolites from South Carolina, Chem. Geol., 212, 45-57, 2004.

Ryu, J.-S., Vigier, N., Lee, S.-W., and Chadwick, O.: Variation of lithium isotope geochemistry during basalt weathering and secondary mineral transformations, Geochim. Cosmochim. Acta, 145, 103-115, 2014.

Syvitski, J. P. M., Peckham, S. D., Hilberman, R., and Mulder, T.: Predicting the terrestrial flux of sediment to the global ocean: a planetary perspective, Sediment. Geol., 162, 5-24, 2003.

Tabor, N. J. and Yapp, C. J.: Coexisting goethite and gibbsite from a high-paleolatitude $\left(55^{\circ} \mathrm{N}\right)$ late Paleocene laterite; concentration and $13 \mathrm{C} / 12 \mathrm{C}$ ratios of occluded $\mathrm{CO} 2$ and associated organic matter, Geochim. Cosmochim. Acta, 69, 5495-5510, 2005.

Tardy, Y., Krempp, G., and Trauth, N.: Le lithium dans les minéraux argileux des ciments et des sols, Cosmochim. Cosmochim. Acta, 36, 397-412, 1972.

Tavlan, M., Thorne, R., and Herrington, R. J.: Uplift and lateritization history of the Caldag ophiolite in the context of Neo-Tethyan 
ophiolite obduction and uplift: implications for the Cenozoic weathering history of western Anatolia, J. Geol. Soc. London, 168, 927-940, 2011,

Taylor, L. L., Banwart, S. A., Valdes, P. J., Leake, J. R., and Beerling, D. J.: Evaluating the effects of terrestrial ecosystems, climate and carbon dioxide on weathering over geological time: a global scale process-based approach, Phil. Trans. R. Soc. B, 367, 565-582, 2012.

Teng, F.-Z., Rudnick, R. L., McDonough, W. F., and Wu, F. Y.: Lithium isotopic systematics of A-type granites and their mafic enclaves: Further constraints on the $\mathrm{Li}$ isotopic composition of the continental crust, Chem. Geol., 262, 370-379, 2009.

Tomascak, P. B.: Developments in the understanding and application of lithium isotopes in the Earth and Planetary Sciences, Rev. Mineral. Geochem., 55, 153-195, 2004.

Vance, D., Teagle, D. A. H., and Foster, G. L.: Variable Quaternary chemical weathering rates and imbalances in marine geochemical budgets, Nature, 458, 493-496, 2009.

Vigier, N., Decarreau, A., Millot, R., Carignan, J., Petit, S., and France-Lanord, C.: Quantifying Li isotope fractionation during smectite formation and implications for the Li cycle, Geochim. Cosmocim. Acta, 72, 780-792, 2008.

Vigier, N., Gislason, S. R., Burton, K. W., Millot, R., and Mokadem, F.: The relationship between riverine lithium isotope composition and silicate weathering rates in Iceland, Earth Planet. Sci. Lett., 287, 434-441, 2009 von Strandmann, P. A. E. P., Burton, K. W., James, R. H., van Calsteren, P., and Gislason, S. R.: Assessing the role of climate on uranium and lithium isotope behaviour in rivers draining a basaltic terrain, Chem. Geol., 270, 227-239, 2010.

Walker, J. C. G., Haysand, P. B., and Kasting, J. F.: A negative feedback mechanism for the long-term stabilization of Earth's surface temperature, J. Geophys. Res., 86, 9776-9782, 1981.

Wanner, C., Sonnenthal, E. L., and Liu, X.-M.: Seawater $\delta^{7} \mathrm{Li}$ : a direct proxy for global $\mathrm{CO}_{2}$ consumption by continental silicate weathering?, Chem. Geol., 381, 154-167, 2014.

Wimpenny, J., Gíslason, S. R, James, R. H, Gannoun, A., Von Strandmann, P., and Burton, K. W.: The behaviour of $\mathrm{Li}$ and $\mathrm{Mg}$ isotopes during primary phase dissolution and secondary mineral formation in basalt, Geochim. Cosmochim. Acta, 74, 52595279, 2010.

Willenbring, J. K. and von Blanckenburg, F.: Long-term stability of global erosion rates and weathering during late-Cenozoic cooling, Nature, 465, 211-214, 2010.

Zachos, J. C., Shackleton, N. J., Revenaugh, J. S., Pälike, H., and Flower, B. P.: Climate response to orbital forcing across the Oligocene-Miocene boundary, Science, 292, 274-277, 2001.

Zachos, J. C., Dickens, G. R., and Zeebe R. E.: An early Cenozoic perspective on greenhouse warming and carbon-cycle dynamics, Nature, 451, 279-283, 2008. 